\title{
Acquisition of Aspartase Activity in Rhizobium leguminosarum WU235
}

\author{
By P. S. POOLE, ${ }^{*}$ M. J. DILWORTH AND A. R. GLENN \\ Nitrogen Fixation Research Group, School of Environmental and Life Sciences, Murdoch \\ University, Murdoch, Western Australia 6150, Australia
}

(Received 6 September 1983; revised 15 November 1983)

\begin{abstract}
Rhizobium leguminosarum WU235 expresses aspartase (EC 4.3.1.1) when grown on aspartate or asparagine as the sole carbon source, but not on glucose or fumarate. Cells grown on glucose plus aspartate, or fumarate plus aspartate, do not express aspartase. Although these results are reminiscent of catabolite control of an inducible enzyme, induction of aspartase cannot be demonstrated in this strain. Aspartase-producing cells synthesize the enzyme after repeated subculture on glucose plus $\mathrm{NH}_{4} \mathrm{Cl}$. Cells grown in glucose plus $\mathrm{NH}_{4} \mathrm{Cl}$ and plated onto aspartate produce different colony sizes; the larger $(0 \cdot 1 \%$ of the total $)$ express aspartase, while the smaller do not. At dilutions sufficient to exclude the large aspartase-producing colonies, a single-sized, aspartase-negative colony was found initially. Such colonies later developed papillae or became cluster colonies; aspartase was produced with papillae formation. The aspartase producing strains were shown, by analysis of native plasmids and periplasmic proteins and by the use of antibiotic resistant strains, to be derived from the parental type. The data suggest that strain WU235 is unable to produce aspartase unless a mutation occurs which leads to constitutive enzyme synthesis. The significance of these observations for studies claiming catabolite repression in Rhizobium is discussed.
\end{abstract}

\section{INTRODUCTION}

Though the development and control of catabolic systems in Rhizobium is important in understanding the root nodule symbiosis, a clear picture of the control of these systems has not yet emerged. While glucose has been reported to repress mannitol dehydrogenase in Rhizobium meliloti (Martinez de Drets \& Arias, 1970) and polyol dehydrogenase in Rhizobium trifolii (Ronson \& Primrose, 1979), it does not significantly represss mannitol dehydrogenase in Rhizobium japonicum (Kuykendall \& Elkan, 1977). Glucose does not repress $\beta$-galactosidase induction in $R$. meliloti (Ucker \& Signer, 1978); glucose and lactose are used simultaneously by $R$. trifolii (De Hollaender \& Stouthamer, 1979). Glucose or succinate have little effect on histidase induction but produce $50 \%$ repression of the 4-hydroxybenzoate oxidation system in Rhizobium leguminosarum (Dilworth et al., 1983); but the consumption rates for histidine and 4hydroxybenzoate were substantially reduced by glucose or succinate.

In the course of a study on amino acid utilization by $R$. leguminosarum WU235, we found it grew well on aspartate as sole carbon and nitrogen source and produced high aspartase activities. Since aspartase is usually regarded as a catabolic rather than a biosynthetic enzyme (Hanson \& Havir, 1972) and is repressed by glucose in Aerobacter aerogenes (Farley \& Lichstein, 1963), we investigated the control of aspartase in this strain.

\section{METHODS}

Strains. Rhizobium leguminosarum WU235 is a prototrophic strain from the culture collection of the Institute of Agriculture, University of Western Australia, Australia.

Media. Bacteria were grown in batch culture at $28^{\circ} \mathrm{C}$ on the liquid minimal medium of Brown \& Dilworth (1975) with nitrogen and carbon sources at $10 \mathrm{~mm}$, phosphate at $0.4 \mathrm{~mm}$ and $\mathrm{pH}$ maintained at 7 with $40 \mathrm{~mm}$ HEPES. Yeast mannitol agar (YMA) has been described by Vincent (1970). 
Enzyme assays. Cells ( $200 \mathrm{ml})$ grown to an $A_{600}^{1} \mathrm{~cm}$ of $0 \cdot 6-1$ were harvested by centrifugation at $22^{\circ} \mathrm{C}$, washed twice in minimal salts medium minus HEPES, nitrogen and carbon source and resuspended in $5 \mathrm{ml} 20 \mathrm{mM}$-HEPES buffer ( $\mathrm{pH} \mathrm{7.5)} \mathrm{containing} 1 \mathrm{mM}$-dithiothreitol. Cells were disrupted at $5^{\circ} \mathrm{C}$ by two passages at $69000 \mathrm{kPa}$ through a French pressure cell (Paton Industries, S. Australia, Australia). Cellular debris was removed by centrifugation at $30000 \mathrm{~g}$ for $20 \mathrm{~min}$ at $4{ }^{\circ} \mathrm{C}$ and the resultant supernatant used in enzyme assays.

Aspartase (L-aspartate ammonia-lyase, EC 4.3.1 1) was assayed in a total volume of $1 \mathrm{ml}$ containing $0.04 \mathrm{mmol}$ diethanolamine/ $\mathrm{HCl}$ buffer (pH 9), $0.05 \mathrm{mmol} \mathrm{L}$-aspartic acid (pH 9), $0.001 \mathrm{mmol} \mathrm{MgCl}_{2}$ and $0.0001 \mathrm{mmol}$ EDTA. The reaction was started by the addition of cell-free extract, or toluenized cells (Dilworth \& Glenn, 1982) and terminated after $15 \mathrm{~min}$ at $30^{\circ} \mathrm{C}$ with $10 \%(\mathrm{w} / \mathrm{v})$ TCA $(0.5 \mathrm{ml})$. Samples were centrifuged and the ammonia concentrations determined by Nesslerization (Dawson et al., 1969). Alternatively, fumarate release was continuously monitored in a spectrophotometer at $240 \mathrm{~nm}$ and activity determined using a molar extinction coefficient of $25001 \mathrm{~mol}^{-1}$ for fumarate (Williams \& Lartigue, 1969). Aspartate aminotransferase (L-aspartate :2oxoglutarate aminotransferase, EC 2.6.1.1) was assayed by the technique of Bergmeyer \& Bernt (1974). Fumarase ( $L$-malate hydro-lyase, EC 4.2.1.2) was assayed spectrophotometrically by measuring fumarate release at $240 \mathrm{~nm}$ in a total volume of $1 \mathrm{ml}$ containing $0.05 \mathrm{mmol}$ phosphate buffer ( $\mathrm{pH} 8$ ) and $0.05 \mathrm{mmol} \mathrm{L-malate.} \mathrm{Protein} \mathrm{was}$ determined by the Lowry method using BSA as the standard.

Plasmid analysis. Plasmids were identified using the method of Eckhardt (1978).

Analysis of periplasmic proteins. Bacteria were grown in liquid minimal medium (Brown \& Dilworth, 1975) with glucose $(10 \mathrm{mM})$ as the carbon source and $\mathrm{NH}_{4} \mathrm{Cl}(10 \mathrm{mM})$ as the nitrogen source. Periplasmic proteins were prepared as described by Glenn \& Dilworth (1979), except that slab gels were used rather than disc gels.

\section{RESULTS AND DISCUSSION}

\section{Enzyme expression}

Inocula for broth cultures of WU235 to be tested for aspartase activity were first cultured on solid media containing the appropriate carbon or nitrogen source. Only cells grown on aspartate or asparagine had substantial activity, consistent with a catabolic role for the enzyme (Table 1). Although the aspartase reaction is reversible (Wilkinson \& Williams, 1961), and a biosynthetic role has been suggested (Kretovich et al., 1981; Halpern \& Umbarger, 1960; Freese et al., 1964), the lack of activity in cells grown on fumarate plus $\mathrm{NH}_{4} \mathrm{Cl}$ strongly suggests that it is not important for biosynthesis in $R$. leguminosarum WU235.

\section{Enzyme properties}

Aspartase activity determined by fumarate release was only $45 \%$ of that measured by ammonia release because of a high fumarase activity $\left[0.33 \mu \mathrm{mol} \mathrm{min}^{-1}(\mathrm{mg} \text { protein })^{-1}\right]$. Since fumarate formation accompanied ammonia production, subsequent assays used ammonia formation only. Enzyme activity was a linear function of protein concentration and time to limiting values of $0.4 \mathrm{mg}$ and $20 \mathrm{~min}$, respectively. Aspartase activity was similar in HEPES, Tris and diethanolamine buffers of the same $\mathrm{pH}$, but Tris promoted colour formation in the Nessler's reaction. The $\mathrm{pH}$ optimum for aspartase was between 8.5 and 9 , with added $\mathrm{MgCl}_{2}$

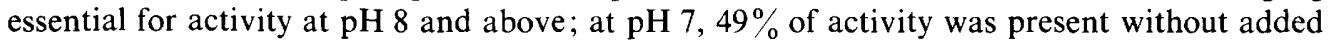
$\mathrm{MgCl}_{2}$, a pattern similar to that for the purified enzyme from Escherichia coli (Suzuki et al., 1973).

Although Kretovich et al. (1981) reported that aspartase activity in extracts of bacteroids of Rhizobium lupini was only $6-7 \%$ of that found in whole bacteroids, ammonia release by toluenized whole cells or cell-free extracts was essentially the same for free-living cells of $R$. leguminosarum.

\section{Binary substrate mixtures}

Inocula for broth cultures of WU235 on binary substrate mixtures were first grown on solid media containing the appropriate mixtures. In liquid cultures, glucose and fumarate prevented expression of aspartase activity, even when aspartate was the only nitrogen source present (Table 1). Adequate levels of aspartate aminotransferase were present to enable at least partial utilization of aspartate without aspartase (Table 1). While these data suggest classical catabolite repression, others to be presented below show this not to be the case. 
Table 1. Aspartase activity in R. leguminosarum WU235 grown on various substrates

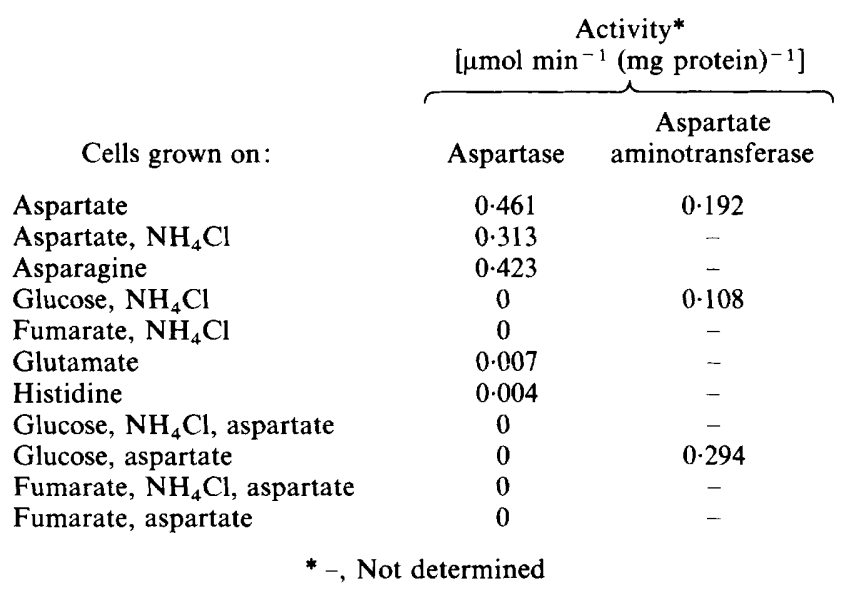

\section{Time course}

The time course of apparent aspartase synthesis was examined by resuspending cells of WU235 grown on glucose plus $\mathrm{NH}_{4} \mathrm{Cl}$ in an aspartate minimal salts medium and assaying at intervals for aspartase activity. No aspartase activity was detected even $26 \mathrm{~h}$ after resuspension in the aspartate medium, though the absorbance of the resuspended cells increased slowly, presumably due to the constitutive aspartate aminotransferase. By contrast, induced histidase activity in $R$. leguminosarum strains WU235 and MNF3841 is detectable 30 min after resuspension and is maximal after $3 \mathrm{~h}$, and 4-hydroxybenzoate oxidation is detected after $2 \mathrm{~h}$ and is fully induced in $8 \mathrm{~h}$ (Dilworth et al., 1983).

There seemed two possible alternatives to explain the apparent paradox of a failure to observe induction of aspartase and its synthesis in cells growing rapidly on aspartate (mean generation time $3.25 \mathrm{~h}$ ): a very long lag phase for enzyme induction or a genetic change in the population. One form of genetic change could be the selection of an aspartase-positive mutant in what is actually an aspartase-negative strain. If the mutant were constitutive, aspartase should be expressed by it even in the presence of glucose or fumarate.

\section{Back-culture}

Cultures of cells plated on aspartate and expressing aspartase were back-cultured twice onto glucose plus $\mathrm{NH}_{4} \mathrm{Cl}$ and the second back-cultures used to inoculate glucose plus $\mathrm{NH}_{4} \mathrm{Cl}$ liquid medium. When the toluenized whole cells were then assayed for aspartase, these cultures consistently retained aspartase activity. The retention of activity was not transient, since one sample subcultured six times before assay retained an aspartase activity of $0.109 \mu \mathrm{mol} \mathrm{min}^{-1}$ (mg protein $)^{-1}$. The specific activity of aspartase in these cells back-cultured in glucose plus $\mathrm{NH}_{4} \mathrm{Cl}$ was lower than the activity of cells grown in aspartate, which may indicate a control effect by glucose.

The data so far are consistent with, but do not establish unequivocally, the selection of a constitutive strain. One consequence of a selection model is that any cells expressing aspartase should grow faster on aspartate than those that only have aspartate aminotransferase. If a stock culture grown on glucose plus $\mathrm{NH}_{4} \mathrm{Cl}$ contains a low frequency of aspartase-constitutive cells or gives rise to such cells by mutation, plating onto aspartate medium should give rise to large colonies of faster-growing aspartase-producing cells at a low frequency. Aspartase-negative cells should either grow slowly or not at all, alternatives which should give different plating efficiencies on aspartate and glucose. 


\section{Plating efficiency}

Cells of WU235 lacking detectable aspartase activity were grown in a glucose plus $\mathrm{NH}_{4} \mathrm{Cl}$ liquid medium, serially diluted in minimal salts and plated onto glucose plus $\mathrm{NH}_{4} \mathrm{Cl}, \mathrm{YMA}$ or aspartate plates. After $4 \mathrm{~d}$ incubation at $28{ }^{\circ} \mathrm{C}$, the viable counts were identical on all three media. However, although only one colony type was present on the glucose plus $\mathrm{NH}_{4} \mathrm{Cl}$ or YMA plates, aspartate plates developed two different sized colony types, with the larger type present at $0.1 \%$ of the frequency of the smaller (Fig. $1 a$ ). Five large and five small colonies were selected, plated onto glucose plus $\mathrm{NH}_{4} \mathrm{Cl}$, inoculated into glucose plus $\mathrm{NH}_{4} \mathrm{Cl}$ liquid medium and the toluenized whole cells assayed for aspartase. No culture from a small colony had any aspartase activity, while all those from the large colonies did $\left[0 \cdot 169 \pm 0.021 \mu \mathrm{mol} \mathrm{min}^{-1}(\mathrm{mg} \text { protein })^{-1}\right]$.

When similar glucose-grown cells of WU235 lacking aspartase were diluted sufficiently to exclude the large colonies, a single homogeneous colony size was found $4 \mathrm{~d}$ after plating onto aspartate. Seven such colonies were plated onto glucose plus $\mathrm{NH}_{4} \mathrm{Cl}$ and then grown in glucose plus $\mathrm{NH}_{4} \mathrm{Cl}$ liquid medium before assay of the toluenized whole cells for aspartase; all lacked activity. After $6 \mathrm{~d}$ papillae began to develop on the colonies on the aspartate plates; by $9 \mathrm{~d}$ these had become substantial nodes and in some cases cluster colonies (Fig. $1 b$ ). Five cluster colonies were streaked on glucose plus $\mathrm{NH}_{4} \mathrm{Cl}$ plates and then inoculated into glucose plus $\mathrm{NH}_{4} \mathrm{Cl}$ liquid medium so that the toluenized whole cells could be assayed for aspartase; all colonies had

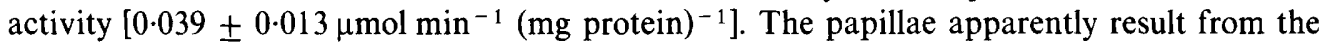
selection of an aspartase-positive mutant arising during formation of the colony. The cluster colonies are thus a mixture of aspartase-positive and negative nodes, resulting in a much lower specific activity of aspartase.

The development of aspartase in papillated colonies largely excludes the possibility of a contaminant in the WU235 culture. These colonies can only be developing aspartase after mutation of individual cells in the colony. Even if the colonies do not arise from a single cell, none of these initial cells can have aspartase, or they would produce the large aspartase-positive colonies.

In order to ascertain that the large aspartase-constitutive colonies were derivatives of the aspartase-negative parental strain, rather than contaminants, a number of other properties of both were examined. PAGE of lysozyme-EDTA extracts of periplasmic proteins (Glenn \& Dilworth, 1979), which allows differentiation of species and strains of Rhizobium (J. Smart, personal communication), revealed either an identical (19/19) or nearly identical (18/19) pattern of protein bands among several independently isolated aspartase-constitutive clones and the parent. Agarose gel electrophoresis of the native rhizobial plasmids in strain WU235 and several aspartase-constitutive strains showed that all contained five large plasmids of identical molecular size. An additional check using plasmids was made by constructing an RP1-carrying strain of WU235. Aspartase constitutive derivatives of WU235(RP1) were isolated and purified as described previously and shown by gel electrophoresis to retain RP1. Finally, antibioticresistant derivatives of WU235 (strr and $s t r^{r}$ rif $^{r}$ ) were isolated and used in aspartate plating experiments. In all cases (30/30 for the $s t^{r}$ and 29/29 str ${ }^{r}$ if ${ }^{r}$ ) the drug resistant markers were retained in the aspartase-constitutive derivative strains.

The frequency at which large colonies occur $(0 \cdot 1 \%$ of the small colonies) is not a mutational frequency, since the mutation for aspartase expression can occur both during growth in liquid culture and during formation of the colony itself. Calculation of a mutational frequency would require a selective medium on which only aspartase positive cells could grow.

We interpret these data to mean that WU235 is an aspartase-negative strain from which constitutive mutants arise. The apparent catabolite repression observed in the binary mixtures of glucose plus aspartate or fumarate plus aspartate would then be due to the rapid growth of cells of WU235 on glucose or fumarate preventing selection for the aspartase-constitutive strain.

Laboratory selection has been widely reported and reviewed for a number of enzyme systems (Mortlock, 1982). One example with a resemblance to the aspartase system is the selection for xylitol utilization in Aerobacter aerogenes 1033 (Lerner et al., 1964; Wu et al., 1968). There the parental strain is unable to use xylitol as a carbon source, but a control mutation resulting in 
(a)

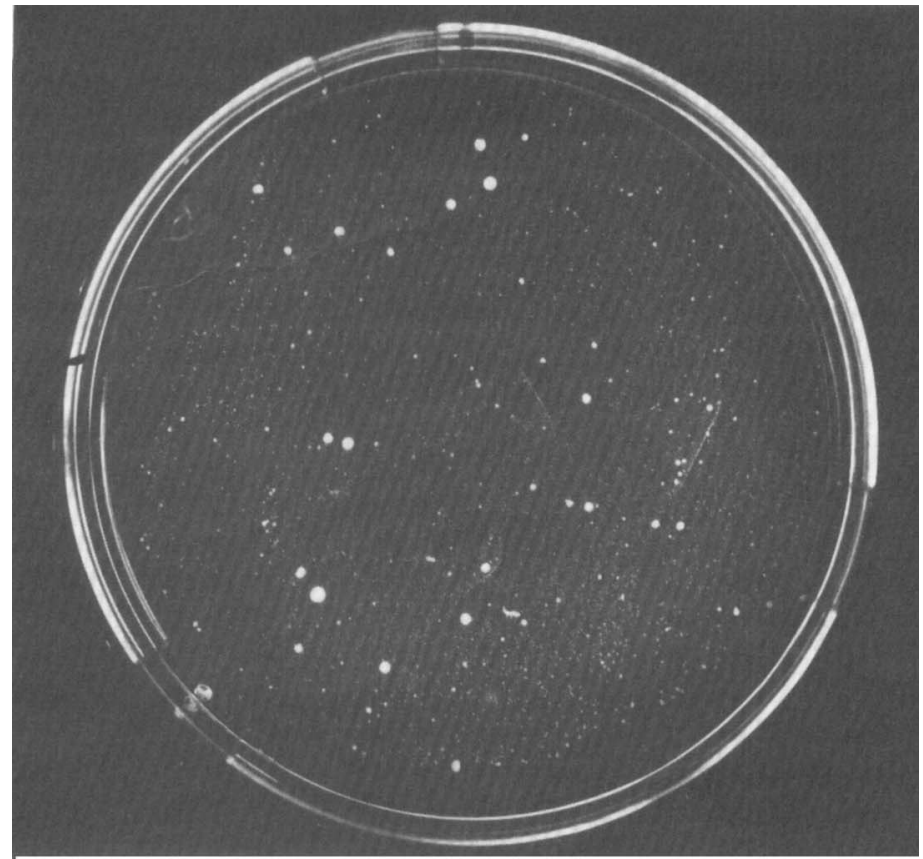

(b)

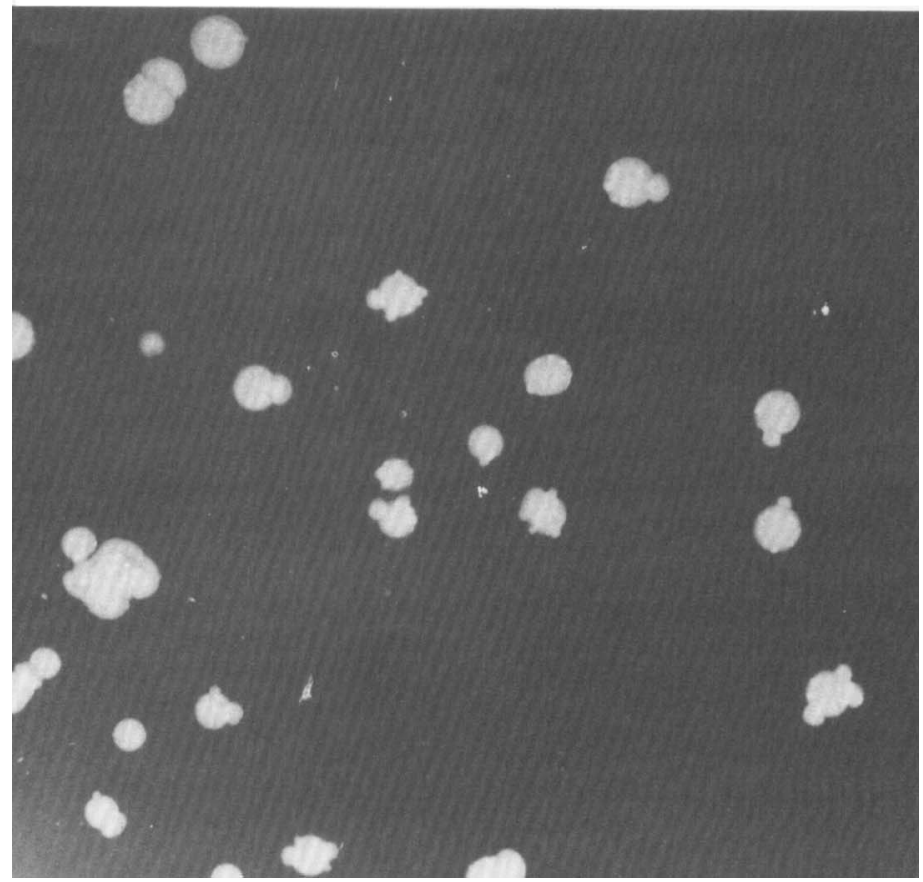

Fig. 1. (a) Different colony sizes in $R$. leguminosarum WU235 grown in glucose plus $\mathrm{NH}_{4} \mathrm{Cl}$ liquid medium and plated onto aspartate. (b) Appearance of papillation on colonies of $R$. leguminosarum WU235 $9 \mathrm{~d}$ after plating on aspartate. 
constitutive synthesis of ribitol dehydrogenase allows growth on xylitol. Primrose \& Ronson (1980) reported that $R$. trifolii 7000 , which will not grow on xylitol, has a dulcitol dehydrogenase which will oxidise xylitol but is not induced by it. The mutant strain $R$. trifolii 7010 which has a constitutive dulcitol dehydrogenase will grow on xylitol.

The data presented in this paper show the ease with which induction and/or repression could be ascribed to an enzyme system without due regard to the possibility of selection. Investigations into catabolite control by Rhizobium should account for this possibility by demonstrating a reasonable induction time or showing loss of the induced activity on back-culture.

We wish to thank Dr R. Arwas for help with the plasmid analysis. This work was supported by the Australian Research Grants Scheme.

\section{REFERENCES}

Bergmeyer, H. U. \& BerNT, E. (1974). Glutamateoxaloacetate transaminase. In Methods of Enzymatic Analysis, vol. 12, pp. 727-773. Edited by H. U. Bergmeyer. New York: Academic Press.

Brown, C. M. \& Dilworth, M. J. (1975). Ammonia assimilation by Rhizobium cultures and bacteroids. Journal of General Microbiology 86, 39-48.

Dawson, R. M. C., Elliott, D. C., Elliott, W. H. \& JONES, K. M. (1969). Preparation and composition of biochemical reagents. In Data for Biochemical Research, pp. 615-623. Oxford: Oxford University Press.

De Hollaender, J. A. \& Stouthamer, A. H. (1979). Multicarbon-substrate growth of Rhizobium trifolii. FEMS Microbiology Letters 6, 57-59.

Dilworth, M. J. \& GLENN, A. (1982). Movements of ammonia in Rhizobium leguminosarum. Journal of General Microbiology 128, 29-37.

Dilworth, M. J., MCKay, I., Franklin, M. \& GlenN, A. R. (1983). Catabolite effects on enzyme induction and substrate utilization in Rhizobium leguminosarum. Journal of General Microbiology 129, 359-366.

ECKHARDT, T. (1978). A rapid method for the identification of plasmid deoxyribonucleic acid in bacteria. Plasmid 1, 584-588.

Farley, M. A. \& Lichstein, H. C. (1963). Glucose inhibition of aspartase synthesis by Aerobacter aerogenes. Canadian Journal of Microbiology 9, 835-842.

Freese, E., Park, S. W. \& Cashel, M. (1964). The developmental significance of alanine dehydrogenase in Bacillus subtilis. Proceedings of the National Academy of Sciences of the United States of America 51, 1164-1172.

GlenN, A. R. \& Dilworth, M. J. (1979). An examination of Rhizobium leguminosarum for the production of extracellular and periplasmic proteins. Journal of General Microbiology 112, 405-409.

HALPern, Y. S. \& UMbarger, H. E. (1960). Conversion of ammonia to amino groups in Escherichia coli. Journal of Bacteriology 80, 285-288.

Hanson, K. R. \& HaviR, E. A. (1972). The enzymic elimination of ammonia. In The Enzymes, vol. 7, pp.
75-166. Edited by P. D. Boyer. New York: Academic Press.

Kretovich, W. L., Kariakina, T. I., Weinova, M. K., Sidelnikova, L. I. \& KaZaKova, O. W. (1981). The synthesis of aspartic acid in Rhizobium lupini bacteroids. Plant and Soil 61, 145-156.

Kuykendall, L. D. \& ElKan, G. H. (1977). Some features of mannitol metabolism in Rhizobium japonicum. Journal of General Microbiology 98, 291295.

Lerner, S. A., Wu, T. T. \& LIN, E. C. C. (1964). Evolution of a catabolic pathway in bacteria. Science 146, 1313-1315.

Martinez de Drets, G. \& Arias, A. (1970). Metabolism of some polyols by Rhizobium meliloti. Journal of Bacteriology 103, 97-103.

MORTLOCK, R. P. (1982). Metabolic acquisitions through laboratory selection. Annual Review of Microbiology 36, 259-284.

Primrose, S. B. \& Ronson, C. W. (1980). Polyol metabolism by Rhizobium trifolii. Journal of Bacteriology 141, 1109-1114.

Ronson, C. W. \& Primrose, S. B. (1979). Effect of glucose on polyol metabolism by Rhizobium trifolii. Journal of Bacteriology 139, 1075-1078.

Suzuki, S., Yamaguchi, J. \& Tokushige, M. (1973). Studies on aspartase. Biochimica et biophysica acta 321, 369-381.

UCKer, D. S. \& Signer, E. R. (1978). Cataboliterepression like phenomenon in Rhizobium meliloti. Journal of Bacteriology 136, 1197-1200.

VINCENT, J. M. (1970). A Manual for the Practical Study of Root-Nodule Bacteria. Oxford: Blackwell Scientific Publications.

Wilkinson, J. S. \& Williams, V. R. (1961). Partial purification of bacterial aspartase by starch electrophoresis. Archives of Biochemistry and Biophysics 93, 80-84.

Williams, V. R. \& Lartigue, D. J. (1969). Aspartase. Methods in Enzymology 13, 354-361.

Wu, T. T., Lin, E. C. C. \& TANaKa, S. (1968). Mutants of Aerobacter aerogenes capable of utilizing xylitol as a novel carbon. Journal of Bacteriology 96, 447-456. 